\title{
Effect of Weed Management and Nutrient Application on Soil Enzyme Activity, pH, EC, Organic Carbon and Available Nutrients in Soil at Harvest of Quality Protein Maize
}

\author{
Versha Gupta*, Arvind Verma, Jai Prakash Bhimwal and S. K. Dhaka
}

Department of Agronomy, Rajasthan College of Agriculture, MPUAT, Udaipur, India

*Corresponding author

\section{A B S T R A C T}

\section{Keywords}

Atrazine, Alachlor, Tembotrione, Quality protein maize, $\mathrm{pH}, \mathrm{EC}$, phosphorus, potassium and sulphur

Article Info

Accepted:

18 May 2020

Available Online:

10 June 2020
A field experiment was conducted during kharif and rabi seasons of 2015-16 and 2016-17 at Udaipur to evaluate the effect of weed and nutrient management on quality protein maize. The experiment consisted of nine weed management treatments viz., weedy check, hand weeding at $15 \mathrm{DAS}$ and $35 \mathrm{DAS}$, tembotrione $0.125 \mathrm{~kg} \mathrm{ha}^{-1}$ at $20 \mathrm{DAS}$, alachlor 2 $\mathrm{kg} \mathrm{ha}^{-1}$ as PE $f b$ hand weeding at $35 \mathrm{DAS}$, atrazine $0.5 \mathrm{~kg} \mathrm{ha}^{-1}$ as PE $f b$ hand weeding at 35 DAS, tembotrione $0.125 \mathrm{~kg} \mathrm{ha}^{-1}$ at 20 DAS $f b$ hand weeding at 35 DAS, alachlor $2 \mathrm{~kg} \mathrm{ha}^{-1}$ + atrazine $0.5 \mathrm{~kg} \mathrm{ha}^{-1}$ as PE $f b$ hand weeding at $35 \mathrm{DAS}$, alachlor $2 \mathrm{~kg} \mathrm{ha}^{-1}$ as PE $f b$ tembotrione $0.125 \mathrm{~kg} \mathrm{ha}^{-1}$ at $20 \mathrm{DAS}$ and atrazine $0.5 \mathrm{~kg} \mathrm{ha}^{-1}$ as PE $f b$ tembotrione 0.125 $\mathrm{kg} \mathrm{ha}^{-1}$ at 20 DAS with three nutrient management treatments viz., NPK, NPK+Zn and NPKS $+Z n$, thereby making 27 treatment combinations. The experiment was laid out in split plot design, assigning weed management to main plots and nutrient management to sub plots. The treatments were replicated thrice. Maize cv. Pratap QPM-1 used as test crop. Soil enzyme activity, $\mathrm{pH}, \mathrm{EC}$ and organic carbon at harvest of QPM were found unaffected with various weed and nutrient management treatments. Further, different weed and nutrient management treatments failed to cause any significant effect on available nitrogen, phosphorus, potassium and sulphur nutrients in soil at harvest of QPM.

\section{Introduction}

Maize (Zea mays L.) also called as the queen of cereals, is one of the major cereal crops with wide adaptability under various diversified agro-climatic edaphic conditions around the world. In this crop, the content of essential amino acids viz., lysine and tryptophan is low while leucine and isoleucine content is high (Jat et al., 2013).
The QPM is a hybridized variety of maize specially bread by addition of Opaque-2 mutant gene, which improve lysine and tryptophan and reduce leucine and isoleucine contents and produce quality protein with balanced composition of amino acids.

Major area of maize in India is during kharif season in which weed is one of the most important yield limiting factor and 
significantly reduces the yield. Maize is infested by a wide range of weed flora, viz., Echinochloa colona, Cyperusrotundus, Cynodon dactylon, Commelina benghalensis, Digera arvensis and Trianthema portulacastrum dominate during early stages of the crop growth and toward the tasseling and maturity of the crop. However, the most critical period for crop weed competition are first six weeks after planting of crop which may reduce yield by $28-100 \%$ (Dass et al., 2012). During this critical period weeding is essentially required by either chemical or non-chemical means. Weeding by hands (labour) and mechanical means are expensive and many a times timely operations are not possible due to continuous rains in monsoon season. However, application of single herbicide does not provide satisfactory weed control for the desired period. Atrazine and alachlor have been widely recommended for effective control of weeds in maize (Tahir et al., 2011). Atrazine, recommended as a preemergence herbicide, is not effective against some of the weeds, both grassy and nongrassy as well as the sedge Cyperus rotundus (Singh et al., 2015). Hence, there is need for some alternate post-emergence herbicide like tembotrione which can provide broad spectrum weed control in kharif maize without affecting the crop growth and yield of crop (Singh et al., 2012 b). Nutrient management also plays key role in sustaining the productivity of this system, QPM is high nutrient requiring ones and respond well to higher levels of chemical fertilizers. Quality protein maize is a nitrogen exhaustive crop and requires very high dose of the nutrient (Singh, 2010 and Om et al., 2014). Thus higher yield of QPM can be obtained through the judicious and higher uses of two major nutrients ( $\mathrm{N}$ and $\mathrm{P}$ ) as these two nutrients alone contribute 40-60 per cent of the crop yield (Das et al., 2010). Among the secondary and micronutrients, $\mathrm{S}$ and $\mathrm{Zn}$ have also a specific vital role in growth and development of crops (Duraisami et al., 2007). It is proven fact that productivity of any crop cannot be further increased by use of high doses of fertilizer alone. So the nutrient management with balanced use of nutrients increases the yield and also maintains soil health.

\section{Materials and Methods}

A field experiment was conducted during kharif and rabi seasons of2015-16 and 201617 at Instructional Farm (Agronomy), Rajasthan College of Agriculture, Udaipur. The site is situated at South-Eastern part of Rajasthan at an altitude of 579.5 metre above mean sea level with $24^{\circ} 35^{\prime} \mathrm{N}$ latitude and $74^{\circ} 42^{\prime}$ E longitude. The region falls under agro-climatic zone IVa (Sub-Humid Southern Plain and Aravalli Hills) of Rajasthan. This zone possesses a typical sub-tropical climatic conditions characterized by mild winters and moderate summers associated with high relative humidity. The mean annual rainfall of the region is $637 \mathrm{~mm}$. Soil of experimental site was clay loam in texture and slightly alkaline in reaction $(\mathrm{pH} 8.1$ and 8.0) and medium in available nitrogen (285.0 and $279.61 \mathrm{~kg} \mathrm{ha}^{-1}$ ) and phosphorus (20.42 and $19.27 \mathrm{~kg} \mathrm{ha}^{-1}$ ) and high in available potassium (324.16 and $318.15 \mathrm{~kg} \mathrm{ha}^{-1}$ ) and low in available sulphur ( 9.7 and $9.3 \mathrm{~kg} \mathrm{ha}^{-1}$ ) during both the years i.e., 2015-16 and 2016-17, respectively. The experiment consisted of nine weed management treatments viz., weedy check, hand weeding at 15 DAS and 35 DAS, tembotrione $0.125 \mathrm{~kg} \mathrm{ha}^{-1}$ at $20 \mathrm{DAS}$, alachlor $2 \mathrm{~kg} \mathrm{ha}^{-1}$ as PE $f b$ hand weeding at 35 DAS, atrazine $0.5 \mathrm{~kg} \mathrm{ha}^{-1}$ as $\mathrm{PE} f b$ hand weeding at $35 \mathrm{DAS}$, tembotrione $0.125 \mathrm{~kg} \mathrm{ha}^{-1}$ at $20 \mathrm{DAS}$ $f b$ hand weeding at 35 DAS, alachlor $2 \mathrm{~kg} \mathrm{ha}^{-1}$ + atrazine $0.5 \mathrm{~kg} \mathrm{ha}^{-1}$ as PE $f b$ hand weeding at $35 \mathrm{DAS}$, alachlor $2 \mathrm{~kg} \mathrm{ha}^{-1}$ as PE $f b$ tembotrione $0.125 \mathrm{~kg} \mathrm{ha}^{-1}$ at 20 DAS and atrazine $0.5 \mathrm{~kg} \mathrm{ha}^{-1}$ as $\mathrm{PE} f b$ tembotrione $0.125 \mathrm{~kg} \mathrm{ha}^{-1}$ at $20 \mathrm{DAS}$ with three nutrient management treatments viz., NPK, NPK+Zn 
and NPKS $+\mathrm{Zn}$, thereby making 27 treatment combinations. The experiment was laid out in split plot design, assigning weed management to main plots and nutrient management to sub plots. The treatments were replicated thrice. Maize cv. Pratap QPM-1 was used as test crop, sown at the seed rate of $20 \mathrm{~kg} \mathrm{ha}^{-1}$ at inter row of 60 and plant to plant spacing of $25 \mathrm{~cm}$. Furrows were opened through desi plough and seeds were sown manually at the depth of $5 \mathrm{~cm}$. As per the treatment full dose of phosphorus, potash, sulphur and zinc and half dose of nitrogen were applied at sowing by drilling in crop rows through urea, DAP, mineral gypsum and zinc sulphate. The remaining dose of nitrogen was top dressed at knee height stage through urea. As per treatment, both atrazine and alachlor were sprayed one day after sowing (as preemergence) while tembotrione was applied twenty days after sowing (as post-emergence) with knapsack sprayer. Random soil samples were drawn at two different locations from each plot up to $15 \mathrm{~cm}$ depth after harvest of the crop. These were air dried and pass through $2 \mathrm{~mm}$ sieve and analyzed for $\mathrm{pH}, \mathrm{EC}$, organic carbon, available $\mathrm{N}, \mathrm{P}$, Kand $\mathrm{S}$, Dehydrogenase, Phosphatase and Urease enzyme activity as per analysis method.

\section{Results and Discussion}

\section{Effect on soil}

Soil enzyme activity viz., Dehydrogenase, Phosphotase and Urease as well as soil $\mathrm{pH}$, EC and organic carbon at harvest of QPM were found unaffected with various weed and nutrient management treatments.

Table.1 Effect of weed management and nutrient application on soil enzyme activity, $\mathrm{pH}$ and EC at harvest of QPM (pooled data of 2 years)

\begin{tabular}{|c|c|c|c|c|c|}
\hline Treatments & $\begin{array}{c}\text { Dehydrogenase } \\
\text { enzyme } \\
\text { activity } \\
\left(\mu \mathrm{g} \mathrm{g}^{-1} \mathbf{h}^{-1}\right)\end{array}$ & $\begin{array}{c}\text { Phosphatase } \\
\text { enzyme activity } \\
\left(\mu \mathrm{g} \mathrm{g}^{-1} \mathrm{~h}^{-1}\right)\end{array}$ & $\begin{array}{c}\text { Urease } \\
\text { enzyme } \\
\text { activity } \\
\left(\mu \mathrm{g} \mathrm{g}^{-1} \mathbf{h}^{-1}\right)\end{array}$ & Soil pH & $\begin{array}{c}\text { Soil EC } \\
\left(\mathbf{d s m}^{-1}\right)\end{array}$ \\
\hline \multicolumn{6}{|l|}{ Weed management } \\
\hline Weedy check & 122.78 & 207.57 & 336.80 & 8.19 & 0.844 \\
\hline Hand weeding 15 \& 35 DAS & 138.23 & 227.96 & 365.14 & 8.27 & 0.880 \\
\hline Tembotrione & 124.67 & 212.30 & 331.41 & 8.22 & 0.855 \\
\hline Alachlor $f b$ hand weeding & 127.53 & 211.04 & 337.18 & 8.22 & 0.845 \\
\hline Atrazine $f b$ hand weeding & 129.09 & 183.61 & 341.80 & 8.22 & 0.855 \\
\hline Tembotrionefbhand weeding & 130.82 & 222.30 & 346.72 & 8.22 & 0.855 \\
\hline $\begin{array}{l}\text { Alachlor+atrazine } f b \text { hand } \\
\text { weeding }\end{array}$ & 131.90 & 205.06 & 351.93 & 8.25 & 0.860 \\
\hline AlachlorfbTembotrione & 136.91 & 221.69 & 356.57 & 8.26 & 0.870 \\
\hline Atrazine $f b$ Tembotrione & 140.18 & 226.97 & 365.86 & 8.27 & 0.880 \\
\hline S.Em. \pm & 4.23 & 7.46 & 10.68 & 0.05 & 0.011 \\
\hline C.D. $(P=0.05)$ & NS & NS & NS & NS & NS \\
\hline \multicolumn{6}{|l|}{ Nutrient management } \\
\hline NPK & 129.86 & 212.24 & 345.36 & 8.24 & 0.859 \\
\hline $\mathrm{NPK}+\mathrm{Zn}$ & 130.84 & 212.44 & 348.42 & 8.24 & 0.861 \\
\hline NPKS+Zn & 133.34 & 214.82 & 350.69 & 8.24 & 0.862 \\
\hline S.Em. \pm & 1.58 & 1.81 & 3.70 & 0.02 & 0.004 \\
\hline $\mathrm{CD}(\mathrm{P}=\mathbf{0 . 0 5})$ & NS & NS & NS & NS & NS \\
\hline
\end{tabular}


Table. 2 Residual effect of weed management and nutrient application on soil organic carbon and available nutrients at harvest of QPM (pooled data of 2 years)

\begin{tabular}{|c|c|c|c|c|c|}
\hline Treatments & $\begin{array}{l}\text { Organic } \\
\text { carbon } \\
\left(\mathrm{g} \mathrm{kg}^{-1}\right)\end{array}$ & $\begin{array}{l}\text { Available } \\
\text { Nitrogen } \\
\left(\text { kg ha }^{-1}\right)\end{array}$ & $\begin{array}{c}\text { Available } \\
\text { Phosphorus } \\
\left(\mathrm{kg} \mathrm{ha}^{-1}\right)\end{array}$ & $\begin{array}{c}\text { Available } \\
\text { Potassium } \\
\left(\mathrm{kg} \mathrm{ha}^{-1}\right)\end{array}$ & $\begin{array}{c}\text { Available } \\
\text { Sulphur } \\
\left(\mathrm{kg} \mathrm{ha}^{-1}\right)\end{array}$ \\
\hline \multicolumn{6}{|l|}{ Weed management } \\
\hline Weedy check & 7.79 & 304.21 & 21.76 & 486.68 & 19.97 \\
\hline Hand weeding $15 \& 35$ DAS & 7.58 & 333.84 & 24.14 & 541.42 & 22.16 \\
\hline Tembotrione & 6.92 & 327.05 & 21.13 & 533.55 & 19.84 \\
\hline Alachlor $f b$ hand weeding & 6.92 & 328.08 & 21.19 & 534.92 & 20.66 \\
\hline Atrazine $f b$ hand weeding & 6.95 & 329.10 & 21.37 & 535.88 & 21.42 \\
\hline Tembotrione $f b$ hand weeding & 6.93 & 326.63 & 21.83 & 534.71 & 20.11 \\
\hline $\begin{array}{l}\text { Alachlor+atrazine } f b \text { hand } \\
\text { weeding }\end{array}$ & 7.36 & 330.83 & 22.09 & 537.52 & 22.51 \\
\hline Alachlorfb Tembotrione & 7.56 & 329.05 & 22.87 & 540.52 & 22.05 \\
\hline Atrazine $f b$ Tembotrione & 7.59 & 335.62 & 24.97 & 549.64 & 22.24 \\
\hline S.Em. \pm & 0.19 & 7.18 & 0.81 & 12.72 & 0.56 \\
\hline C.D. $(P=0.05)$ & NS & NS & NS & NS & NS \\
\hline \multicolumn{6}{|l|}{ Nutrient management } \\
\hline NPK & 7.27 & 326.41 & 22.35 & 532.07 & 21.07 \\
\hline $\mathrm{NPK}+\mathrm{Zn}$ & 7.31 & 327.04 & 22.39 & 532.61 & 21.21 \\
\hline NPKS +Zn & 7.29 & 328.03 & 22.38 & 533.61 & 21.37 \\
\hline S.Em. \pm & 0.07 & 2.20 & 0.17 & 3.84 & 0.17 \\
\hline $\mathrm{CD}(\mathrm{P}=\mathbf{0 . 0 5})$ & NS & NS & NS & NS & NS \\
\hline
\end{tabular}

Further, different weed and nutrient management treatments failed to cause any significant effect on available nitrogen, phosphorus, potassium and sulphur nutrients in soil at harvest of QPM.

\section{References}

Das, A., Patel, D.P., Munda, G.C. and Ghosh, P.K. 2010. Effect of organic and inorganic sources of nutrients on yield, nutrient uptake and soil fertility of maize (Zea mays) - mustard (Brassica campestris) cropping system. Indian Journal of Agricultural Sciences 80: 8588.

Dass, S., Kumar, A., Jat, S.L., Parihar, C.M., Singh, A.K., Chikkappa, G.K. and Jat, M.L. 2012. Maize holds potential for diversification and livelihood security. Indian Journal of Agronomy 57 ( $3^{\text {rd }}$
IAC Special Issue): 32-37.

Duraisami, V.P., Chitdeshwari, T., Subramanian, K.S. and Rajeswari R. 2007. Research Notes Effect of micronutrients and sulphur on yield and nutrient uptake by maize in an alfisol. Madras Agricultural Journal 94: 283288.

Jat, S.L., Parihar, C.M., Singh, A.K., Jat, M.L., Sinha, A.K., Mishra, B.N., Meena, H., Paradkar, V.K., Singh, C.S., Singh, D. and Singh, R.N. 2013. Integrated nutrient management in quality protein maize (Zea mays L.) planted in rotation with wheat (Triticum aestivum L.). Indian Journal of Agricultural Sciences 83: 391-396.

Om, H., Singh, S. P., Singh, J. K., Singh, R. N., Ansari, M. A., Meena, R. L. and Yadav, B. 2014. Productivity, nitrogen balance and economics of winter maize 
(Zea mays L.) as influenced by QPM cultivars and nitrogen levels. Indian Journal of Agricultural Sciences84: 306-308.

Singh, A. K., Parihar, C. M., Jat, S. L., Singh, B. and Sharma, S. 2015.Effect on weed dynamics, productivity and economics of the maize-wheat (Triticum aestivum) cropping system in Indo-gangetic plains. Indian Journal of Agricultural Sciences 85: 87-92.

Singh, D. 2010. Impact of scheduling on nitrogen on productivity of single cross maize (Zea mays L.) hybrids. Indian Journal of Agricultural Science80: 649-
651.

Singh V.P., Guru, S.K., Kumar, A., Banga, A. and Tripathi, N. 2012 b. Bioefficacy of tembotrione against mixed weed complex in maize. Indian Journal of Weed Science44(1): 1-5.

Tahir, M., Shabbir, G., Nadeem, M.A., Waseem, M., Javid, H.M.R. and Rehman, H. 2011. The effect of intensity of tillage and herbicide application on spring planted maize (Zea mays L.) and its weeds. Pakistan Journal of Life and Social Sciences9 (2): 109-115.

\section{How to cite this article:}

Versha Gupta, Arvind Verma, Jai Prakash Bhimwal and Dhaka. S. K. 2020. Effect of Weed Management and Nutrient Application on Soil Enzyme Activity, pH, EC, Organic Carbon and Available Nutrients in Soil at Harvest of Quality Protein Maize. Int.J.Curr.Microbiol.App.Sci. 9(06): 2117-2121. doi: https://doi.org/10.20546/ijcmas.2020.906.259 